\title{
NITROGEN AND SILICON FERTILIZATION OF UPLAND RICE
}

\author{
Munir Mauad ${ }^{1}$; Carlos Alexandre Costa Crusciol ${ }^{1 *}$; Hélio Grassi Filho²; Juliano Corulli Corrêa ${ }^{1}$ \\ ${ }^{1}$ UNESP/FCA - Depto. de Produção Vegetal, C.P. 237, 18603-970 - Botucatu, SP - Brasil. \\ ${ }^{2}$ UNESP/FCA - Depto. de Recursos Naturais. \\ *Corresponding author <crusciol@fca.unesp.br>
}

\begin{abstract}
Silicon is not considered an essential element for plant development and growth, but its absorption brings several benefits to some crops, especially rice, by increasing cellular wall thickness, providing mechanical resistance to the penetration of fungi, improving the opening angle of leaves and making them more erect, decreasing self-shading and increasing resistance to lodging, especially under high nitrogen rates. To evaluate the effects of nitrogen and silicon fertilization on vegetative and yield components, plant height, and yield of rice cultivar IAC 202, an experiment was carried out combining three nitrogen rates $(5,75$ and $150 \mathrm{mg} \mathrm{N} \mathrm{kg}^{-1}$ soil) applied as urea, and four silicon rates $\left(0,200,400\right.$ and $600 \mathrm{mg} \mathrm{SiO} \mathrm{kg}^{-1}$ soil) applied as calcium silicate. Trial was set up in a completely randomized design $3 \times 4$ factorial scheme, $(\mathrm{N}=5)$. Nitrogen fertilization increased the number of stems and panicles per square meter and the total number of spikelets, reflecting on grain productivity. Excessive tillering caused by inadequate nitrogen fertilization reduced the percentage of fertile stalks, spikelet fertility and grain mass. Silicon fertilization reduced the number of blank spikelets per panicles and increased grain mass, but did not affect grain productivity.
\end{abstract}

Key words: Oryza sativa L., silicon, nitrogen, yield components

\section{ADUBAÇÃO NITROGENADA E SILICATADA DO ARROZ DE TERRAS ALTAS}

\begin{abstract}
RESUMO: O silício não é considerado um elemento essencial para o crescimento e desenvolvimento das plantas, entretanto, sua absorção traz inúmeros benefícios, principalmente ao arroz, como aumento da espessura da parede celular, conferindo resistência mecânica a penetração de fungos, melhora o ângulo de abertura das folhas tornando-as mais eretas, diminuindo o auto-sombreamento e aumentando a resistência ao acamamento, especialmente sob altas doses de nitrogênio. O presente trabalho teve por objetivo avaliar os efeitos da adubação nitrogenada e silicatada nos componentes vegetativos, nos componentes da produção, na altura da planta e na produtividade da cultivar de arroz IAC 202. O experimento foi constituído da combinação de três doses de

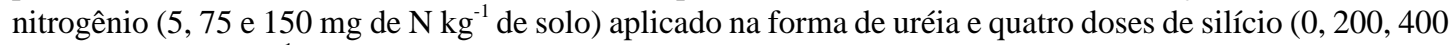
e $600 \mathrm{mg} \mathrm{de} \mathrm{SiO}_{2} \mathrm{~kg}^{-1}$ de solo), aplicado na forma de silicato de cálcio. O delineamento experimental utilizado foi o inteiramente casualizado em esquema fatorial $3 \times 4(\mathrm{~N}=5)$. A adubação nitrogenada aumentou o número de colmos e panículas por metro quadrado e o número total de espiguetas, refletindo na produtividade de grãos. O perfilhamento excessivo causado pela adubação nitrogenada inadequada causou redução na porcentagem de colmos férteis, na fertilidade das espiguetas e da massa de grãos. A adubação silicatada reduziu o número de espiguetas chochas por panícula e aumentou a massa de grãos sem, contudo, refletir na produtividade de grãos.

Palavras-chave: Oryza sativa L., silício, nitrogênio, componentes da produção
\end{abstract}

\section{INTRODUCTION}

Rice is a staple food in the diet of the Brazilian population and is produced throughout the country, under different conditions and production systems. In the upland ecosystem, rice is grown in dryland or sprinklerirrigated systems, and represent $66 \%$ of the total rice planted area of Brazil, but contributes only $31 \%$ to the country's rice production. The low productivity of rice obtained in dryland systems is a consequence of a set of biotic and abiotic factors, among which are the occurrence of diseases, inadequate rainfall distribution in the main producing regions and little use of fertilizers and lime.
The search for new technologies that will enable the expansion of the producing area as well as productivity has featured the use of silicon fertilization in rice crops as a promising alternative.

Silicon is not considered within the group of nutrients that are essential or functional for plant growth, but its absorption brings several benefits, especially for rice, such as the increase of cell wall thickness below the cuticle (Yoshida et al., 1962) imparting mechanical resistance to the penetration of fungi, decrease in transpiration (Yoshida et al., 1962), and improvement of the leaf angle, making leaves more erect, thus reducing self-shading, especially under high nitrogen rates (Yoshida et al., 1969). 
In terms of yield components, silicon increases the number of spikelets per panicle (Ma et al., 1989; Deren et al., 1994; Takahashi, 1995), spikelet fertility (Barbosa Filho, 1987; Takahashi, 1995), and the mass of grains (Balastra et al., 1989; Carvalho, 2000). With regard to the number of panicles, results found in the literature are contradictory: Takahashi (1995) found an increase for this trait, while Ma et al. (1989), Deren et al. (1994) and Carvalho (2000) did not observe significant increases. This demonstrates that the element is essential, from an agronomic standpoint, to increase and/or provide sustainable yields of rice crop (Barbosa Filho et al., 2000).

Nitrogen is essential for plant growth and development, and is often a limiting factor for high productivities. However, when applied in excess it may limit yield because of lodging, especially for cultivars of the traditional and intermediate groups, and promote shading and disease problems. These effects could be minimized by the use of silicon. Therefore, this paper aims to evaluate the effect of silicon and nitrogen rates on upland rice, and their interaction with yield components and grain productivity.

\section{MATERIAL AND METHODS}

The experiment was installed and conducted inside a plastic tunnel house from 11/30/99 to $03 / 25 / 00$, in Botucatu, SP. Brazil. The soil was a dystrophic Clayed, Rhodic Hapludox, and its chemical analysis indicates: $\mathrm{P}=1 \mathrm{mg} \mathrm{dm}^{-3}$; O.M. $=16 \mathrm{mg} \mathrm{m}^{-3}, \mathrm{pH}\left(\mathrm{CaCl}_{2} 0.01 \mathrm{~mol} \mathrm{~L}^{-1}\right)$ $=4.0 ; \mathrm{H}+\mathrm{Al}=64.4 \mathrm{mmol} \mathrm{dm}^{-3} ; \mathrm{K}^{+}=0.14 \mathrm{mmol} \mathrm{dm}^{-3}$;

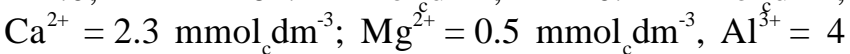
mmol $\mathrm{dm}^{-3}$, and $\mathrm{V} \%=4.36$. Liming was performed 60 days before sowing to raise the V\% to 50 (Raij et al., 1996), using dolomitic lime with a ECCE of $85 \%$.

The experimental design consisted of a completely randomized design, $3 \times 4$ factorial scheme, with five replicates. Each unit consisted of a pot with internal dimensions of $40 \times 40 \times 25 \mathrm{~cm}$, containing $30 \mathrm{~kg}$ of soil and 2 sowing rows $40 \mathrm{~cm}$ in length and spaced $20 \mathrm{~cm}$ apart. The rice cultivar was IAC-202.

Treatments corresponded to the application of 5 , 75 and $150 \mathrm{mg} \mathrm{N} \mathrm{kg}^{-1}$ soil, as urea $(45 \% \mathrm{~N})$, and 0,200 , 400 and $600 \mathrm{mg} \mathrm{SiO} \mathrm{kg}^{-1}$ soil, equivalent to $0,93,187$ and $280 \mathrm{mg} \mathrm{Si} \mathrm{kg}^{-1}$ soil, utilizing calcium silicate (Wollastonite): total silicon oxide $\left(\mathrm{SiO}_{2}\right)=45.2 \%$; $\mathrm{pH}$ in water $=7.0$ to 7.5 ; solubility in water negligible; $91 \%$ calcium silicate.

Sowing was performed on 11/30/99, using 70 viable seeds per row. Emergence date was considered to be six days after sowing, when $50 \%$ of the seedlings in each experimental unit showed coleoptile above the soil level. Thinning was made nine days after emergence, to 30 plants per row.
Fertilization at sowing consisted of $5 \mathrm{mg} \mathrm{N} \mathrm{kg}^{-1}$ soil for all pots, plus $100 \mathrm{mg} \mathrm{P} \mathrm{kg}^{-1}$ soil (single superphosphate, $18 \% \mathrm{P}_{2} \mathrm{O}_{5}$ ) and $150 \mathrm{mg} \mathrm{K} \mathrm{kg}^{-1}$ (potassium chloride, $60 \% \mathrm{~K}_{2} \mathrm{O}$ ). Nitrogen sidedressing was carried out 35 days after emergence, using 70 and $145 \mathrm{mg} \mathrm{N} \mathrm{kg}^{-1}$ soil. Silicate was incorporated into the soil 30 days before sowing.

One of the sowing rows was utilized to determine plant height, number of stalks and panicles per square meter, percentage of fertile stalks, numbers of grained and blank spikelets per panicle, spikelet fertility, mass of 1000 grains and productivity. Recorded date were submitted a variance analysis. For nitrogen factor, results were compared by the Tukey test 0.05 , while for the silicon factor and interaction of the factors (nitrogen $\mathrm{x}$ silicon), a regression analysis study was carried out.

\section{RESULTS AND DISCUSSION}

No foliar diseases occurred during the experiment. The number of stalks was associated to sowing density and to tillering ability of the genotype. As all experimental units were maintained with 30 plants, the observed increase in the number of stalks as a response to nitrogen fertilization was related to the cultivar stimulation to produce tillers, which is related to the greater nitrogen availability to plants (Table 1 ).

The number of panicles is defined during the period from germination to ten days after the panicle primordium is visible (Fornasieri Filho \& Fornasieri, 1993; Machado 1994), since it occurs as a direct function of the number of stalks depending, therefore, on genetic and environmental factors. Increment of panicle number occurred with increasing nitrogen rates (Table 1). This behavior is a consequence of the participation of $\mathrm{N}$ in structural functions of the plant, such as cell multiplication and differentiation, genic inheritance and formation of tissues (Malavolta et al., 1997). These results agree with those reported by Barbosa Filho (1987, 1991), Fornasieri Filho \& Fornasieri (1993), and Arf (1993).

Results found for silicon contradict those obtained by Barbosa Filho (1987) and Takahaski (1995), but agree with those of Ma et al. (1989), Deren et al. (1994) and Carvalho (2000), who also did not find significant differences for number of panicles. Silicon would have little effect on the vegetative stage, at which this component is defined (Ma et al., 1989). Since no organic molecule is known to be associated to silicon in plants (Exley, 1998), no statement can be made about the influence this element has on defining this component.

The number of stalks does not constitute an yield component, neither does the percentage of fertile stalks. This variable expresses the percentage of stalks that actually produced a panicle, which decrease with increasing rate of $\mathrm{N}$ (Table 1). The reduction in fertile stalks 
Table 1 - Number of stalks and panicles per $\mathrm{m}^{2}$, percentage of fertile stalk, total number of spikelets and number of grained spikelets, and percentage of fertile spikelets in upland rice, as a function of silicon and nitrogen rates ${ }^{1}$.

\begin{tabular}{|c|c|c|c|c|c|c|c|}
\hline \multirow{2}{*}{ Treatment } & \multirow{2}{*}{ Stalks $\mathrm{m}^{-2}$} & \multirow{2}{*}{ Panicles $\mathrm{m}^{-2}$} & \multirow{2}{*}{ Fertile stalk } & \multicolumn{3}{|c|}{ Spikelets } & \multirow[t]{2}{*}{ Fertile spikelets } \\
\hline & & & & Total & Grained & Blank & \\
\hline $\begin{array}{l}\text { Rates of } \mathrm{N} \\
\text { (mg/kg solo) }\end{array}$ & - & $\circ-1-1-1$ & $\%$ & $-\cdots--$ & $\cdots n^{\circ}$ & & $\%$ \\
\hline 5 & $484 \mathrm{c}$ & $421 \mathrm{~b}$ & 88 a & $62 \mathrm{~b}$ & $55 \mathrm{~b}$ & 7 & 89 a \\
\hline 75 & $696 \mathrm{~b}$ & $628 \mathrm{a}$ & $90 \mathrm{a}$ & 79 a & $68 \mathrm{a}$ & 11 & $86 \mathrm{a}$ \\
\hline 150 & 824 a & $628 \mathrm{a}$ & $77 \mathrm{~b}$ & $86 a$ & $61 \mathrm{ab}$ & 24 & $71 \mathrm{~b}$ \\
\hline \multicolumn{8}{|l|}{$\begin{array}{l}\text { Rates of } \mathrm{SiO}_{2} \\
(\mathrm{mg} / \mathrm{kg} \text { solo })\end{array}$} \\
\hline 0 & 653 & 542 & 85 & 79 & 64 & 14 & 84 \\
\hline 200 & 655 & 549 & 85 & 78 & 63 & 14 & 83 \\
\hline 400 & 705 & 580 & 84 & 73 & 59 & 15 & 82 \\
\hline 600 & 658 & 565 & 88 & 72 & 58 & 13 & 81 \\
\hline \multicolumn{8}{|c|}{ Values of $F^{2}$} \\
\hline Rates of $\mathrm{N}$ & $110.50 * *$ & $60.56 * *$ & $10.48 * *$ & $17.48 * *$ & $6.34 *$ & $51.21 * *$ & $41.74 * *$ \\
\hline Rates of $\mathrm{Si}$ & $1.75 \mathrm{~ns}$ & $0.94 \mathrm{~ns}$ & $0.24 \mathrm{~ns}$ & $1.16 \mathrm{~ns}$ & $1.38 \mathrm{~ns}$ & $0.23 \mathrm{~ns}$ & $0.82 \mathrm{~ns}$ \\
\hline $\mathrm{N} \times \mathrm{Si}$ & $0.56 \mathrm{~ns}$ & $0.86 \mathrm{~ns}$ & $0.76 \mathrm{~ns}$ & $1.70 \mathrm{~ns}$ & $0.63 \mathrm{~ns}$ & $2.91 *$ & $1.33 \mathrm{~ns}$ \\
\hline $\mathrm{CV}(\%)$ & 10.9 & 12.2 & 11.7 & 17.5 & 19.2 & 40.2 & 7.7 \\
\hline
\end{tabular}

${ }^{1}$ Means followed by a common letter do not differ by Tukey test 0.05 .

$2 * *, *$ e ns, respectively: significant at the 0.01 and 0.05 probability, and non significant.

could be related to the greater number of stalks produced as nitrogen fertilization increased, which could have caused a smaller number of vegetative buds to become reproductive. High nitrogen rates induce the formation of large number of stalks and leaves, creating unfavorable conditions to yielding, such as shading and lodging (Barbosa Filho, 1987 and 1991). The increase in number of stalks, provided by the increasing rates of nitrogen fertilization, contributed to increase the number of leaves, which could have caused shading, decreasing the area of active photosynthesis and diminishing the production of carbohydrates. This would not have been sufficient to ensure panicle primordium differentiation, panicle growth and stalk elongation. As a consequence, some stalks produced panicles, and others did not.

The total number of spikelets is determined during the reproductive stage (Fornasieri Filho \& Fornasieri, 1993; Machado, 1994). The definition of this component begins with the differentiation of the vegetative into a reproductive bud, giving origin to the panicle primordium, and ends at booting (Machado, 1994). Nitrogen fertilization elicited an increase of this variable (Table 1), and the result is associated to a greater availability of nitrogen, since this nutrient is related to the formation of tissues (Malavolta et al., 1997). In addition, in the case of rice, the little availability of this element during the period between differentiation of the panicle primordium and differentiation of spikelets in the panicle branches, significantly reduces this yield component (Fornasieri Filho \& Fornasieri, 1993). This result agrees with reports of Barbosa Filho (1987), but goes against those of Arf
(1993), who did not obtain an increase in the number of spikelets per panicle as the levels of nitrogen increased. That probably happened because $\mathrm{N}$ contents in the soil were at a sufficient level for spikelets on panicle branches to differentiate, and because the cultivars utilized belonged to the traditional group, particularly characterized by their poor response to nitrogen fertilization.

Silicon rates did not influence number of spikelets per panicle $(P>0.05)$ in opposition to results of Deren et al. (1994) and Barbosa Filho (1987), who verified a positive response to the application of this element. However, Carvalho (2000), also did not observe any influence of silicon fertilization on this yield component.

The number of grain-bearing spikelets also differed for nitrogen rates; higher values were recorded for the rate of $75 \mathrm{mg}$ of $\mathrm{N} \mathrm{kg}^{-1}$ of soil (Table 1). The tendency of reduction observed in the rate of $150 \mathrm{mg}$ de $\mathrm{N} \mathrm{kg}^{-1}$ ) was probably caused by self-shading, resulting from greater leafiness and decumbence of leaves, yielding smaller production of photoassimilates. No differences were found for effects of silicon rates on grained spikelets $(P>0.05)$, conversely to reports by Barbosa Filho (1987). The reproductive stage is the most affected by the absence of silicon, with a reduction of up to $40 \%$ in the number of grain-bearing spikelets, and $10 \%$ in the total number of spikelets per panicle (Ma et al., 1989).

The number of blank spikelets was influenced by the $\mathrm{N} \times \mathrm{Si}$ interaction. Notwithstanding, only the highest $\mathrm{N}$ rate was affected by the application of $\mathrm{Si}$, resulting in a decrease in the number of blank spikelets (Figure 1). Such effect can be explained by improvement in plant 


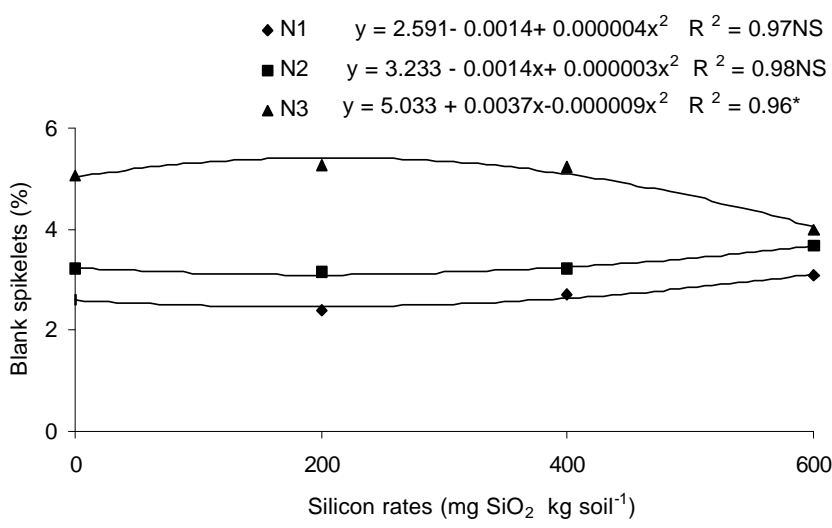

Figure 1 - Percentage of blank spikelets in upland rice as a function of silicon rates, when submitted to different nitrogen rates. $\left(\mathrm{N}_{1}=5 ; \mathrm{N}_{2}=75\right.$ and $\mathrm{N}_{3}=150 \mathrm{mg} \mathrm{N} \mathrm{kg}^{-1}$ soil $)$

architecture (Deren et al., 1994), which results in smaller opening of the leaf angle verified visually in the present work. Leaves become more erect, thus reducing self-shading and increasing photosynthesis rate, especially under conditions of high population densities and high doses of nitrogen (Yoshida et al., 1969), as observed. The combination between high nitrogen rates and the absence and/or low silicon rates tend to turn leaves more decumbent, as a result of greater leaf opening angles (Yoshida et al., 1969). As it was observed at the rates of 5 and $75 \mathrm{mg} \mathrm{N} \mathrm{kg}^{-1}$ soil, increasing levels of silicon fertilization did not change the number of blank spikelets. However, at the rate of 150 $\mathrm{mg} \mathrm{N} \mathrm{kg}{ }^{-1}$ soil, number of blank spikelets decreased with increasing levels of silicon fertilization.

Spikelet fertility expresses the percentage of spikelets that turned into grain. This yield component is dependent upon pollen grain meiosis, anthesis, pollination, fertilization and carbohydrate translocation, and is influenced by prevalent environmental conditions, especially around 10 days before and after flowering, as well as by excessive rates of nitrogen fertilizers (Machado, 1994).

Nitrogen fertilization did modify spikelet fertility. This behavior could be related to the fact that at the vegetative stage there was greater amount of nitrogen available for the plant, which increased tillering and number of panicles (Table 1). Greater tillering caused shading, reducing the area of active photosynthesis, therefore reducing the production of assimilates, that otherwise would be directed to grain filling, and increasing the number of blank spikelets, consequently reducing spikelet fertility.

Silicon seems to play a role on spikelet fertility, but no mechanism or action site through which silicon would act on this yield component is known (Ma et al., 1989). No effect of silicon rates on spikelet fertility was observed in the present study.

Only nitrogen rates affected plant height. A reduction in plant height was observed as nitrogen rate in-
Table 2 - Plant height, mass of 1000 grains and productivity in upland rice as a function of silicon and nitrogen rates ${ }^{1}$.

\begin{tabular}{lccc}
\hline \multicolumn{1}{c}{ Treatment } & $\begin{array}{c}\text { Plant } \\
\text { height }\end{array}$ & $\begin{array}{c}\text { Mass of } 1000 \\
\text { grains }\end{array}$ & Productivity \\
\hline $\begin{array}{l}\text { Rates of } \mathrm{N} \\
\left(\mathrm{mg} \mathrm{kg}^{-1} \text { solo) }\right.\end{array}$ & $\mathrm{cm}$ & $\mathrm{g}$ & $\mathrm{kg} \mathrm{ha}^{-1}$ \\
5 & $62.2 \mathrm{~b}$ & $25.2 \mathrm{a}$ & $5114 \mathrm{c}$ \\
75 & $64.1 \mathrm{a}$ & $22.0 \mathrm{~b}$ & $7890 \mathrm{a}$ \\
150 & $62.4 \mathrm{ab}$ & $20.4 \mathrm{c}$ & $6440 \mathrm{~b}$
\end{tabular}

Rates of $\mathrm{SiO}_{2}$ (mg kg-1 solo)

\begin{tabular}{llll}
0 & 64.5 & $21.6 \mathrm{~b}$ & 6180 \\
200 & 65.3 & $22.5 \mathrm{ab}$ & 6500 \\
400 & 65.8 & $23.2 \mathrm{a}$ & 6650 \\
600 & 63.3 & $22.8 \mathrm{ab}$ & 6550 \\
Values of $\mathrm{F}^{2}$ & & & \\
Rates of $\mathrm{N}$ & $3.73 *$ & $58.58 * *$ & $16.48 * *$ \\
Rates of Si & $0.75 \mathrm{~ns}$ & $3.56 *$ & $0.28 \mathrm{~ns}$ \\
$\mathrm{~N} \mathrm{x} \mathrm{Si}$ & $0.60 \mathrm{~ns}$ & $2.11 \mathrm{~ns}$ & $0.88 \mathrm{~ns}$ \\
\hline $\mathrm{CV}(\%)$ & 6.7 & 6.3 & 23.6 \\
\hline
\end{tabular}

${ }^{1}$ Means followed by a common letter do not differ by Tukey test $(\mathrm{P}<0.05)$

$2 * * *$ e ns, respectively: significant at the 0.01 and 0.05 probability, and non significant.

creased. This result contradicts findings by Arf (1993), who observed increasing plant height with increasing nitrogen fertilization level.

Grain mass is a quite stable variety trait, and depends on hull size, determined during the two weeks that precede anthesis, and on caryopsis development after flowering. Therefore, it depends on carbohydrate translocation, in the first seven days, to fill the hull in the direction of its length, and in the seven days that follow, to increase in width and thickness (Machado, 1994).

Increasing nitrogen rates reduced the mass of 1,000 grains (Table 2), probably because the amount of carbohydrates was not sufficient to fill the greater number of spikelets produced (Table 1). These results are similar to those obtained by Arf (1993), who verified a reduction in the mass of 100 grains for cultivar Rio Paranaíba in the order of $0.0011 \mathrm{~g}$ per $\mathrm{kg}$ of applied nitrogen. However, they diverge from results of Stone et al. (1999), who did not observe differences for the mass of 1,000 grains as nitrogen rates increased.

The mass of 1,000 grains increased as the level of silicon fertilization increased (Figure 2). Even though silicon deposition on rice grain hulls was not evaluated, the likely explanation for the increase in grain mass would be the greater deposition of this element on the paleae and lemmas, as reported by Balastra et al (1989). This greater deposition is attributed to intense panicle transpiration during the grain filling stage, since the process of transportation and deposition of silicon in plant 


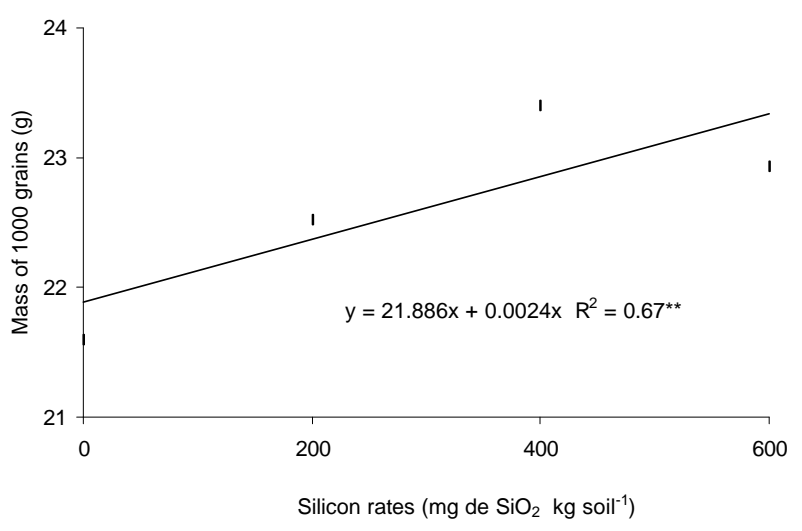

Figure 2 - Mass of 1000 grains in upland rice as a function of silicon rates.

tissues depends upon the transpiration rates that occur in different plant organs (Yoshida et al. 1962). When a given plant organ is developing, transpiration tends to become more intense, and consequently silicon deposition tends to be higher. This result corroborates those found by Balastra et al. (1989), Deren et al. (1994) and Carvalho (2000), who also observed increasing grain mass with increasing levels of silicon fertilization.

When the results of grain yield are analyzed (Table 2), the higher yield occurred in the rate of $75 \mathrm{mg}$ of $\mathrm{N} \mathrm{kg}^{-1}$ of soil. The application of the higher $\mathrm{N}$ rates did not reflect in yield improvement, but in reduction. High nitrogen rates stimulate tillering and the formation of new leaves, causing shading, a condition that favor diseases, lodging and reductions in productivity (Malavolta \& Fornasieri Filho, 1983; Barbosa Filho, 1987; 1991). No lodging or diseases were observed. Therefore, reduction in productivity with increasing nitrogen fertilization level probably resulted from the sum of several factors, particularly the increase in number of stalks (Table 1) and greater leaf development, which created shading conditions, diminishing the leaf area for active photosynthesis. That caused plants not to have enough carbohydrates to fill up all spikelets produced as the nitrogen fertilization level increased (Table 1), contributing to increase the number of blank spikelets and to decrease fertility (Table 1 ), lowering productivity.

\section{REFERENCES}

ARF, O. Efeito de densidade populacional e adubação nitrogenada sobre o comportamento de cultivares de arroz irrigado por aspersão. Ilha Solteira: UNESP, 1993. 63p. (Livre Docência)
BALASTRA, M.L.F.; PEREZ, C.M.; JULIANO, B.O.; VILLREAL, P. Effects of sílica level on some proprieties of Oriza sativa straw and hult. Canadian Journal of Botany,v.67, p.2356-2363, 1989.

BARBOSA FILHO, M.P. Nutrição e adubação do arroz. Piracicaba: Associação Brasileira para Pesquisa da Potassa e do Fosfato, 1987. 127p.

BARBOSA FILHO, M.P. Adubação do arroz de sequeiro. Informe Agropecuário, n. 14 p.32-38, 1991.

BARBOSA FILHO, M.P.; SNYDER, G.H.; PRABHU, A.S.; DATNOFF, L.E.; KORNDÖRFER, G.H. Importância do silício para a cultura do arroz (uma revisão de literatura) Informações Agronômicas, n.89, p.1$8,2000$.

CARVALHO, J.C. Análise de crescimento e produção de grãos da cultura do arroz irrigado por aspersão em função da aplicação de escórias de siderurgia como fonte de silício. Botucatu: UNESP/FCA, 2000. 119p. (Dissertação - Mestrado)

DEREN, C.W.; DATNOFF, L.E.; SNYDER, G.H.; MARTIN, F.G. Silicon concentration, disease response, and yield components of rice genotypes grown on flooded organic histosols. Crop Science, v.34, p.733-737, 1994.

EXLEY, C. Silicon in life: a bioinorganic solution to bioorganic essentiality. Journal of Inorganic Biochemistry, v.69, p.139-144, 1998.

FORNASIERI FILHO, D.; FORNASIERI, J.L. Manual da cultura do arroz. Jaboticabal: FUNEP, 1993. 221p.

MA, J.; NISHIMRA, K.; TAKAHASHI, E. Effect of silicon on the growth of rice plant at different growth stages. Soil Science and Plant Nutrition, v.35, p.347-356, 1989.

MACHADO, J.R. Desenvolvimento da planta e produtividade de grãos de populações de arroz (Oryza sativa 1.) irrigado por inundação em função de épocas de cultivo. Botucatu: UNESP/FCA, 1994. 237p. (Tese - Livre Docência).

MALAVOLTA, E.; FORNASIERI FILHO, D. Nutrição mineral da cultura do arroz. In: FERREIRA, M.E.; YAMADA, T.; MALAVOLTA, E. Cultura do arroz de sequeiro fatores afetando a produtividade. Piracicaba: Instituto da Potassa \& Fosfata, 1983, p.95-143.

MALAVOLTA, E.; VITTI. G.S.; OLIVEIRA de. S.A. Avaliação do estado nutricional das plantas: princípios e aplicações. 2.ed. Piracicaba: POTAFOS, 1997. 319p.

RAIJ, B.Van.; CANTARELLA, H.; QUAGGIO, J.A; FURLANI, A.M.C. Recomendações de adubação e calagem para o estado de São Paulo, 2.ed. Campinas: Instituto Agronômico - Fundação IAC, 1996. 285p.

STONE, L.F.; SILVEIRA, P.M.; MOREIRA, J.A.A.; YOKOYAMA, L.P. Adubação nitrogênada em arroz de sob irrigação suplementar por aspersão. Pesquisa Agropecuária Brasileira., v.34, p.929-932, 1999.

TAKAHASHI, E. Uptake mode and physiological functions of silica. In: MATUSUO, T.; KUMAZAWA, K.; ISHII, R.; ISHIHARA, K.; HIRATA, H. Science of rice plant physiology. Tokio: Nobunkyo, 1995. v.2, cap.5, p.420-433.

YOSHIDA, S.; OHNISHI, Y.; KITAGISHI, K. Chemical forms, mobility and deposition of silicon in rice plant. Soil Science and Plant Nutrition, v.8, p.15-21, 1962 .

YOSHIDA, S.; NAVESER, S.A.; RAMIREZ, E.A. Effects of silica and nitrogen supply on some leaf characters of rice plant. Plant and Soil, v.31, p.48-56, 1969.

$\overline{\text { Received April 02, }} 2002$

Accepted August 12, 2003 